\title{
ABeta amyloidosis, Dutch type
}

INSERM

\section{Source}

INSERM. (1999). Orphanet: an online rare disease and orphan drug data base. ABeta amyloidosis, Dutch type. ORPHA:100006

Hereditary cerebral hemorrhage with amyloidosis, Dutch type (HCHWA-D) is a form of HCHWA (see this term), a group of familial central nervous system disorders, characterized by severe cerebral amyloid angiopathy (CAA), hemorrhagic and nonhemorrhagic strokes and dementia. 